\title{
CORRECTION
}

\section{Correction to: The Genus Coccidella Hambleton (Hemiptera: Rhizoecidae) with Description of Two New Species}

\author{
MB Kaydan ${ }^{1,2,3}$, Z Konczné Benedicty ${ }^{1}$, T Kondo $^{4}$, AA Ramos-Portilla ${ }^{5}$, É Szita ${ }^{1}$ \\ ${ }^{1}$ Plant Protection Institute, Centre for Agricultural Research, Hungarian Academy of Sciences, Budapest, Hungary \\ ${ }^{2}$ Imamoglu Vocational School, Çukurova Üniv, Adana, Turkey \\ ${ }^{3}$ Çukurova Univ Biotechnology Research Centre, Adana, Turkey \\ ${ }^{4}$ Corporación Colombiana de Investigación Agropecuaria (CORPOICA), Centro de Investigación Palmira, Palmira, Valle, Colombia \\ ${ }^{5}$ Instituto Colombiano Agropecuario ICA, Grupo Sistemática de Insectos Agronomía, Museo Entomológico UNAB, Facultad de Agronomía, \\ Univ Nacional de Colombia, Bogotá, Colombia
}

\section{Correction to: Neotrop Entomol \\ https://doi.org/10.1007/s13744-017-0566-3}

Due to an unfortunate turn of events, the initials of the third author appeared incorrectly in the original publication as the name should have read T Kondo.

The correct representation of the authors' names and their affiliation is listed here and should be treated as definitive. We apologize to authors and readers for the inconvenience. 